\title{
Teknik Role Playing dalam Mengurangi bullying di SMP Muhammadiyah 3 Jakarta
}

\author{
Siti Maemunah ${ }^{1^{*}}$, Yeni Karneli ${ }^{2}$ \\ ${ }^{1}$ Pascasarjana, UHAMKA,Indonesia \\ ${ }^{2}$ Program Pendidikan Profesi Konselor (PPPK), UNP, Indonesia \\ *stmae77@gmail.com
}

\begin{abstract}
School is a place to build relationships or change student behavior permanently in the personality as a member of society. In student social relations, there are many disturbances or problems. One of the actions that harm others that is of concern today is violence between students or what is known as bullying. bullying behavior occurs in the types of physical, verbal, relational, and cyber bullying. One of the guidance and counseling services that can be done is group guidance using role playing techniques. Role playing is considered to reduce bullying behavior through role playing. In role playing students play the role of other people so that the meaning of roles will be faster for students to understand. Thus, students can find out the negative impact that occurs on victims of bullying and can reduce bullying behavior. The method used in this research is the action research of Guidance and Counseling (PTBK) with the implementation of collaborative research with BK teachers at SMP Muhammadiyah 3 Jakarta, as tutor teachers, practitioners and researchers as observers. The data collection techniques used were interviews and observation. The results showed that there was a decrease in bullying behavior as seen from the comparison of the frequency of bullying behavior of students. This shows that role playing techniques are effective in reducing bullying behavior at SMP Muhammadiyah 3 Jakarta.
\end{abstract}

\section{Abstrak}

Sekolah merupakan tempat membangun hubungan atau mengubah perilaku siswa cara menetap dalam kepribadian sebagai anggota masyarakat. Dalam hubungan sosial siswa, banyak terjadi gangguan atau masalah. Salah satu tindakan yang merugikan orang lain yang menjadi perhatian saat ini adalah tindakan kekerasan antar siswa atau yang dikenal dengan istilah bullying. Perilaku bullying terjadi dalam jenis bullying fisik, verbal, relasional, maupun cyber bullying. Salah satu layanan bimbingan dan konseling yang dapat dilakukan adalah bimbingan kelompok menggunakan teknik role playing. Role playing dianggap dapat mereduksi perilaku bullying melalui bermain peran. Dalam role playing peserta didik memainkan peran sebagai orang lain sehingga pemaknaan peranakan lebih cepat untuk dipahami peserta didik. Dengan demikian, peserta didik dapat mengetahui dampak negatif yang terjadi pada korban bullying dan dapat mereduksi perilaku bullying. Metode yang digunakan dalam penelitian ini adalah penelitian tindakan Bimbingan dan Konseling (PTBK) dengan pelaksanaan penelitian secara kolaboratif dengan guru BK SMP

\section{Article Information:}

Received Ferbuary 27, 2021

Revised March 1, 2021

Accepted March 9, 2021

Keywords: education; bullying; role playing.

Kata Kunci: Pendidikan; bullying; role playing.

How to cite: Maemunah, S., \& Karneli, Y. (2021). Teknik Role Playing dalam Mengurangi bullying di SMP Muhammadiyah 3 Jakarta. Prophetic Guidance and Counseling Journal, 2(1). doi: 10.32832/pro-gcj.v2i1.4729 E-ISSN: 2614-1566

Published by: LPPM Universitas Ibn Khaldun Bogor \& Program Studi BKPI UIKA 
Muhammadiyah 3 Jakarta, selaku guru pamong, praktikan dan peneliti sebagai observer. Teknik pengumpulan data yang digunakan adalah wawancara dan observasi. Hasil penelitian menunjukkan bahwa terjadi penurunan perilaku bullying yang terlihat dari perbandingan frekuensi perilaku bullying peser terdidik. Hal tersebut menunjukkan bahwa teknik role playing efektif untuk mereduksi perilaku bullying di SMP Muhammadiyah 3 Jakarta.

\section{Pendahuluan}

Berbagai aksi kekerasan kerap terjadi di lingkungan sekolah. Belakangan ini dalam dunia pendidikan semakin marak berita mengenai kasus bullying yang menimpa peserta didik di lembaga pendidikan. Beberapa kasus yang paling menyita perhatian yaitu; Siswa salah satu Sekolah Menengah Atas (SMA) di Pekanbaru, Riau berinisial FA mengalami patah tulang hidung. Menurut pengakuan FA, ia dibully oleh teman-temannya di sekolah, tak hanya dibully, FA juga diancam dan diperas. Selain dibully hingga mengalami patah tulang hidung, korban juga dipaksa mengaku bahwa dirinya terjatuh. Kasus bullying yang berawal dari bercanda dan berujung pada pemerasan dan patah tulang hidung tersebut terjadi pada November 2020. Selain itu, kasus serupa juga terjadi pada seorang siswa SD Negeri di Kecamatan Wirosari, Kabupaten Grobogan berinisial RS mengalami depresi berat usai diduga menjadi korban perundungan oleh teman-temannya. Ironisnya, RS dibully selama dua tahun atau sejak ia duduk di bangku kelas IV SD. Pribadi RS kemudian berubah. RS sering mengurung diri, takut bertemu dengan orang hingga tak mau lagi bersekolah. Keluarganya pun menghabiskan banyak dana untuk memeriksakan kondisi psikis anaknya. Padahal penghasilan mereka pas-pasan. Awal mula bullying terjadi gara-gara jam dinding. Saat duduk di kelas IV, RS bermain sepak bola di dalam kelas. Bola yang ditendang RS mengenai jam dinding hingga jatuh ke lantai. Sejak saat RS selalu dibully, bahkan pernah disekap di kelas oleh teman-teman sekelas. Rambutnya dijambak, diludahi, disiram air, dan kekerasan lain. Kasus lain yang juga menjadi sorotan adalah MS, seorang siswa kelas VII Sekolah Menengah Pertama (SMP) Negeri 16 Kota Malang, Jawa Timur diduga menjadi korban bully oleh sejumlah temannya. Bahkan, dua ruas jari tengah MS terpaksa diamputasi akibat tindakan teman-temannya. Ia juga kerap menangis akibat syok usai jarinya diamputasi. Oleh temantemannya, MS Diangkat beramai-ramai begitu. Terus dibanting ke paving dalam kondisi terlentang. Aksi itu dilakukan saat jam istirahat sekolah.

Berdasarkan temuan lapangan, masalah yang terjadi di SMP Muhammadiyah 3 Jakarta diantaranya yaitu perilaku anak yang agresif yang merugikan teman di lingkungan sekitar sekolah. Perilaku merugikan teman dan infrastruktur yang tersedia di sekolah terjadi setiap hari, bahkan banyak siswa yang tiap hari mengadu sebagai korban bullying di sekolah. bullying yang terjadi di SMP Muhammadiyah 3 Jakarta, tidak hanya terjadi antar siswa saja, hal ini juga umum terjadi di antara siswi-siswi dan merupakan hal yang lumrah adanya. Hal ini disampaikan oleh guru BK (Bimbingan dan Konseling) SMP Muhammadiyah 3 Jakarta. Frekuensi pengaduan yang tinggi pada guru, menggambarkan betapa seringnya bullying terjadi di sekolah. Selain itu, masalah yang dilakukan anak yaitu perilaku anak yang sulit dikendalikan. Hal ini dapat dibuktikan pada saat berinteraksi langsung dengan anak, dimana anak sangat sulit untuk diatur dan diarahkan. Dilihat dari segi akademik, prestasi belajar siswa cenderung turun dan hal ini dapat diamati dari bukti tertulis pada rapor anak dan kemampuan kognitif anak pada saat berada di dalam kelas. Keadaan ini banyak dikeluhkan para siswa khususnya korban yang merasa tidak nyaman belajar di sekolah karena adanya berbagai bentuk bullying.

bullying adalah perilaku agresif dan negatif seseorang atau sekelompok orang seseorang secara berulang kali yang menyalahgunakan ketidakseimbangan kekuatan dengan tujuan 
untuk menyakiti targetnya (korban) secara mental atau secara fisik. Ketidakseimbangan kekuatan antara pelaku bullying dan target (korban) bisa bersifat nyata misalnya berupa ukuran badan, kekuatan fisik, gender (jenis kelamin), dan status sosial. Contoh yang bersifat perasaan misalnya perasaan lebih superior dan kepandaian bicara atau pandai bersilat lidah.

Jika perilaku bullying terhadap peserta didik dapat dikurangi melalui layanan konseling kelompok dengan teknik role playing, maka peserta didik dapat menjalani kehidupan dengan nyaman dan aman serta dapat mengembangkan potensi yang dimiliki. Bermain peran (role playing) biasanya digunakan dalam konseling kelompok dimana melibatkan orang lain. Anggota kelompok lain dapat berperan sebagai ego state yang bermasalah dengan konseli. Dalam kegiatan ini konseli berlatih dengan anggota kelompok untuk bertingkah laku sesuai dengan apa yang akan diuji coba didunia nyata.

Sejumlah penelitian dilakukan terkait Teknik role playing dalam mengurangi kasus bullying di sekolah. Teknik bermain peran dapat mengurangi perilaku bullying pada siswa kelas VIII SMP N 1 Tempel Sleman Yogyakarta. Perilaku bullying sebelum diberikan treatment sebagian besar dalam kategori sedang. Setelah diberikan treatment menggunakan metode role playing terjadi kesadaran pelaku dapat menurunkan/mengurangi perilaku bullying. Selain itu terdapat peningkatan empati dari saksi perilaku bullying sehingga dapat menekan perilaku bullying (Krisnadi, 2017). Teknik role playing juga terbukti efektif digunakan untuk mengembangkan sikap empati siswa. Teknik role playing dikatakan efektif karena berfungsi sebagai pemahaman tentang emosi, motivasi dan aksi (Diah, 2017). Teknik role playing efektif untuk meningkatkan motivasi berprestasi peserta didik underachiever SMA BPI 1 kota Bandung Tahun Ajaran 2015/2016. Keefektifan teknik role playing terlihat dari uji-t yang menunjukkan perbedaan nilai aspek motivasi berprestasi peserta didik underachiever kelompok eksperimen dengan peserta didik underachiever kelompok kontrol. Keefektifan teknik role playing juga ditunjang dengan adanya perubahan sikap yang diperlihatkan oleh peserta didik underachiever sebelum, dan setelah pemberian perlakuan, dibuktikan melalui hasil jurnal harian, penilaian yang dilakukan peserta didik underachiever terpilih sebagai penilai, beserta observasi (Azis, 2016).

Berbagai penelitian dilakukan mengenai Teknik role playing dalam mengurangi kasus bullying yang terjadi di sekolah, namun setiap penelitian pastinya memiliki perbedaan, seperti dalam penelitian yang dilakukan; terdapat perbedaan dengan judul penelitian yang diteliti yaitu dari segi objek yang dituju, aspek yang diamati, pemberian perlakuan kepada peserta didik, tetapi dari banyak perbedaan ada pula persamaan dengan penelitian saya yaitu memakai teknik role playing untuk mengurangi atau menekan perilaku bullying pada peserta didik.

Metode role playing diharapkan dapat mengurangi bullying pada siswa SMP Muhammadiyah 3 Jakarta dengan dukungan dan kerja sama dari berbagai pihak. bullying akan terus terjadi apabila tak ada tindakan yang efektif dan mampu diterima siswa baik secara verbal dan nonverbal. Keterkaitan penelitian ini dengan bidang bimbingan konseling adalah memberikan layanan pribadi dan sosial mengenai bullying. Siswa diharapkan mampu berperan aktif dalam mengurangi tindakan bullying yang terjadi. Melalui metode role playing pelaku bullying diposisikan menjadi korban agar merasakan apa yang dirasa korban saat dibully sehingga akan sadar tindakannya menyakiti perasaan dan tidak mengulangi kembali. Korban bullying dibalik peranya menjadi pelaku bullying agar dia dapat menyadari bahwa segala bentuk bullying itu salah dan tidak akan menjadi pelaku bullying dikemudian hari. Bagi saksi bullying dengan melihat role playing dapat berperan aktif guna mengurangi perilaku bullying. Saksi dapat mengingatkan kesalahan pelaku bullying atau melaporkan pada guru bahwa telah terjadi perilaku bullying. 


\section{Metode Penelitian}

Penelitian ini dilaksanakan di SMP Muhammadiyah 3 Jakarta, dengan sasaran kelas VII dan kelas VIII, dengan waktu pelaksanaan pada Januari hingga Februari 2020. Pelaksanaan kegiatan meliputi; persiapan penelitian, koordinasi persiapan tindakan, pelaksanaan (perencanaan, tindakan, observasi dan refleksi), penyusunan penelitian, penyempurnaan laporan berdasarkan masukan dalam seminar. Fokus penelitian pada aplikasi Teknik role playing dalam mengurangi kasus bullying di SMP Muhammadiyah 3 Jakarta dan juga pemberian alternatif penyelesaian masalah dalam setiap kasus bullying yang ditemukan.

Penerapan Teknik Role Playing untuk Mereduksi Perilaku bullying pada Peserta Didik di SMP Muhammadiyah 3 Jakarta, secara umum bertujuan untuk mereduksi perilaku bullying pada peserta didik melalui layanan bimbingan kelompok dengan teknik role playing. Jenis penelitian yang digunakan penelitian ini adalah penelitian tindakan Bimbingan dan Konseling (PTBK) dengan pelaksanaan penelitian kolaboratif dengan guru BK SMP Muhammadiyah 3 Jakarta sebagai praktikan dan peneliti sebagai observer. PTBK dalam pengertian ini diorientasikan pada PTK. Penelitian tindakan kelas merupakan penelitian yang dilakukan oleh guru di dalam kelasnya sendiri melalui refleksi diri, dengan tujuan untuk memperbaiki kinerjanya sebagai guru, sehingga hasil belajar peserta didik menjadi meningkat (Wardhani, 2007). Desain penelitian yang digunakan mengacu pada model Kemmis \& Mc Taggart. Dalam perencanaannya, Kemmis menggunakan sistem spiral refleksi diri yang dimulai dengan Rencana; Tindakan; Pengamatan; dan Refleksi dan perencanaan kembali (Kusumah dan Dwitagama, 2010).

Kasus yang diperoleh dalam penelitian ini adalah masalah perilaku bullying yang dialami oleh peserta didik kelas VII dan VIII. Subjek penelitian didasarkan atas rekomendasi guru bimbingan dan konseling sekolah, dan laporan dari beberapa peserta didik. Teknik pengumpulan data yang digunakan antara lain observasi proses yaitu kondisi di mana peneliti tidak ikut serta dalam aktivitas proses layanan yang dilakukan, karena dalam kegiatan layanan peran peneliti hanyalah sebagai observer yang membantu guru bimbingan dan konseling sebagai pelaksana layanan dalam mengobservasi proses pelaksanaan layanan, dan observasi hasil yaitu observasi yang dilakukan oleh beberapa peserta didik tersebut bertujuan untuk mengamati perilaku keseharian para pelaku bullying tanpa sepengetahuan mereka.

Penelitian tindakan kelas ini dilakukan dalam bentuk siklus, siklus yang dirancang dalam penelitian ini sebanyak 2 siklus dan dalam tiap siklus terdiri dari 1 atau 2 pertemuan sesuai dengan kebutuhan yang sewaktu-waktu bisa berubah. Masing-masing siklus memiliki 4 tahapan yaitu: melakukan perencanaan, menentukan tindakan, melakukan pengamatan, serta melakukan refleksi pada hasil. Setelah siklus 1 dilakukan selanjutnya mempersiapkan perencanaan ulang untuk siklus 2 yang didasarkan pada hasil pengamatan pada siklus 1 .

\section{Hasil dan Pembahasan}

\section{A. Temuan penelitian}

Dari hasil pengamatan diperoleh data bahwa terdapat siswa yang memiliki perilaku dan kebiasaan melakukan bullying, perilaku dan tindakan ini sering di lakukan oleh beberapa siswa ketika berada di lingkungan sekolah. Siswa yang sering melakukan tindakan bullying ketika mereka sedang pelajaran berlangsung, tidak suka dengan apa yang di perbuat teman, yang dimiliki teman dan ambisi ingin menguasai. Dari beberapa siswa yang kerap melakukan aksi bullying tersebut ada satu siswa diantaranya yang menjadi pemimpin untuk melakukan tindakan bullying, sedangkan yang lain mengikuti dan ikut melakukan tindakan bullying. Hampir 
setiap tindakan bullying dilakukan, bahkan ketika dilakukan, siswa yang kerap melakukan aksi bullying tersebut ingin menguasai dan ingin mendapatkan perhatian.

Berdasarkan hasil observasi dan wawancara, maka prosedur pelaksanaan role playing yang dilakukan, yaitu meliputi (1) Pertemuan-1 (Perkenalan dan memaparkan materi tentang bullying), (2) Pertemuan-2 (Role playing 1), (3) Pertemuan-3 (Role playing 2), (4) Pertemuan4 (Role playing 3), (5) Pertemuan-5 (Evaluasi dan penutup). Jika permasalahan belum tuntas, maka perlu dilakukan bimbingan dan konseling lebih lanjut oleh guru bimbingan dan konseling guna menindak lanjuti permasalahan secara lebih dalam, agar permasalahan bias teratasi dengan maksimal.

Tujuan yang ingin dicapai adalah untuk mengetahui bagaimana efektivitas penurunan perilaku bullying dengan penerapan teknik role playing pada kelas VII dan VIII di SMP Muhammadiyah 3 Jakarta. Permasalahan tersebut dikemukakan berdasarkan studi kelayakan dan realitas yang ada, karena sebelum masuk pada Tindakan siklus 1, dilakukan observasi guna mengidentifikasi permasalahan yang terjadi dan mengetahui perbandingan sebelum dan sesudah diberikan tindakan. Observasi awal dilakukan dengan mengumpulkan data frekuensi perilaku bullying peserta didik yang dikumpulkan dalam kurun waktu satu minggu dengan menggunakan lembar observasi yang diisi oleh peserta didik sebelum diberikan tindakan, observasi awal menunjukkan tingginya frekuensi perilaku bullying. Setelah di lakukan observasi kemudian penelitian lebih lanjut dilakukan, permasalahan yang terjadi akan dibuktikan secara empiris. Di dalam penelitian ini terdapat beberapa temuan terkait dengan permasalahan yang diteliti. Permasalahan yang muncul yaitu ada beberapa siswa yang melakukan bullying kepada temannya di lingkungan sekolah, di tandai adanya ciri-ciri perilaku bullying yang dilakukan oleh beberapa siswa, diantaranya: (1) sering mengejek teman, (2) berperilaku tidak sopan dan terlihat arogan, (3) berkata tidak pantas terhadap teman, (4) menghina teman, (5) sering menjadi provokator teman, (6) suka mengancam teman, (7) melakukan kekerasan terhadap teman yang tidak disukai.

\section{B. Tindakan Siklus 1}

Pada awal tindakan, siswa diberikan penjelasan mengenai jalannya role playing. Selain itu, diberikan penjelasan mengenai tugas masing-masing peran pada setiap kelompok. Peserta didik yang berperan sebagai pelaku bullying diberikan materi tentang apa yang harus mereka lakukan, bagi korban bullying juga diberikan penjelasan mengenai sikap korban saat mendapat perlakuan bullying dan kepada saksi perilaku bullying juga diberikan penjelasan tentang bagaimana keterlibatan saksi dalam perilaku bullying.

Secara keseluruhan, peserta didik yang berperan sebagai pelaku bullying mendalami perannya dan melakukan tindakan bullying seperti pada keadaan sesungguhnya, sehingga proses tindakan I berjalan dengan cukup baik mulai awal sampai dengan akhir role playing. Pada akhir dari role playing, peserta didik secara bersama-sama menyimpulkan makna dan nilai dari role playing peran yang mereka lakukan. Sebagian besar peserta didik terlihat antusias dan serius dalam mengikuti kegiatan.

\section{Tindakan Siklus II}

Secara keseluruhan, peserta didik terlihat serius dan antusias dalam mengikuti proses role playing, memperhatikan dan terlibat secara aktif sehingga proses tindakan II berjalan dengan cukup baik mulai awal sampai dengan akhir role playing. Pada akhir dari role playing, peserta didik secara bersama-sama menyimpulkan makna role playing yang sudah mereka pelajari bersama. Kegiatan selanjutnya adalah mendiskusikan makna dari peran dan tindakan yang sudah dilakukan. Beberapa peserta didik secara suka rela memberikan pendapatnya. Beberapa peserta didik yang menjadi saksi menjelaskan bahwa perilaku bullying sangat 
merugikan orang lain dan membuat permusuhan dalam berteman. Salah satu peserta didik yang berperan menjadi saksi juga menambahkan bahwa korban bullying harusnya berani tegas dan melawan jika mengalami perilaku bullying.

Hasil tindakan siklus II menunjukkan penurunan perilaku bullying terlihat dari perbandingan frekuensi perilaku bullying peserta didik. Dapat diketahui bahwa perilaku bullying peserta didik yang sebelumnya pada siklus I sudah mengalami pengurangan jika dibandingkan dengan frekuensi perilaku bullying peserta didik pada pratindakan kembali mengalami pengurangan yang jauh lebih signifikan pada siklus II. Ini berarti penerapan teknik role playing efektif untuk mereduksi perilaku bullying peserta didik di SMP Muhammadiyah 3 Jakarta.

\section{Kesimpulan}

Hasil observasi, wawancara dan dokumentasi yang kemudian dianalisis, menunjukkan penerapan teknik role playing efektif dalam mereduksi perilaku bullying. Pada pelaksanaan teknik role playing disimpulkan bahwa: sebelum dilaksanakan teknik role playing siswa sering melakukan tindakan bullying kepada teman sebaya, seperti: mengejek, berkata kasar, sering intimidasi/mengancam bahkan melakukan tindakan fisik. Setelah diberikan treatment teknik role playing, ada perubahan pada siswa menjadi lebih baik, yaitu: kurangnya tindakan mengejek, berkata kasar, mengintimidasi dan memukul juga mengalami penurunan yang baik.

\section{Daftar Pustaka}

Astuti, P.R. (2008). Meredam bullying 3 Cara Efektif Meredam K.P.A. (Kekerasan Pada Anak).Jakarta: Grasindo.

Coloroso, B. (2006). The bullying, The Bullied, and The Bystander. New York: Chapin Company. Fikri, D.A. (2018). 4 Kasus bullying Paling Menggemparkan di Indonesia, Korbannya Ada yang Meninggal. Tersedia [online] https://lifestyle.okezone.com/read/2018/05/04/196/1894566/4-kasus- bullying paling menggemparkan-di-indonesia-korbannya-ada-yang-meninggal? page $=1$.

Darmansyah, 2011. Strategi Pembelajaran Menyenangkan dengan Humor. Jakarta: Bumi Aksara

Gomba, C dan Tsai, K.C. (2012). Effects of bullying in Schools: The Teachers' Perspectives. Journal of Society and Communication Volume 2012, 161-179 ISSN 2200-6591.

Kurniawan, D.E. dan Pranowo, T.A. (2018). Bimbingan Kelompok dengan Teknik Sosiodrama Sebagai Upaya Mengatasi Perilaku bullying di Sekolah. Jurnal Bimbingan dan Konseling Terapan, Volume 02 Number 012018 ISSN: Print 2549-4511 - Online 2549-9092.

Kusumah, W. dan Dwitagama, D. (2010). Mengenal Penelitian Tindakan Kelas. Jakarta: PT INDEKS.

Lexy J. Moleong, 2004. Metodologi Penelitian Kualitatif. Bandung: PT Remaja Rosdakarya.

Nurridha, L. dan Novianti, A. (2017). Kasus bullying Meningkat, Pelaku Didominasi oleh Remaja. Tersedia [online] https://kumparan.com/@kumparanstyle/kasusbullyingmeningkat-pelaku-didominasi-oleh-rem aja.

Sudjana, N. (2005). Dasar-dasar Proses Belajar Mengajar. Bandung: Sinar BaruAlgensindo. 